\title{
CHINESE ENGAGEMENT IN
AFRICA: FRAGMENTED POWER AND GHANAIAN GOLD Nicholas Loubere
}

\begin{abstract}
CHINA'S EXPANDING presence in Africa is a topic of great interest and often consternation - in African and non-African countries alike. Western news outlets in particular have spent considerable energy reporting on China's increasing influence and power on the African continent, with commentators suggesting that China is playing a strategic game to displace
\end{abstract} Western hegemony. ${ }^{1}$ Chinese President Xi Jinping's flagship Belt and Road Initiative (BRI) has become more concrete and expanded rapidly in recent years - now including projects in 71 countries and investments totalling more than US $\$ 210$ billion. ${ }^{2}$ At the same time, reporting on China in Africa has increasingly taken a more urgent tone, replete with dire warnings of debt-trap development and new colonialism with Chinese characteristics. ${ }^{3}$ The dominant narrative in foreign media depicts China's presence in Africa (and, by implication, elsewhere) as ominous - a vision that sociologist Ching Kwan Lee has termed 'the spectre of global China'. ${ }^{4}$

This narrative presupposes a monolithic China unwaveringly pushing forward a unified and coherent global strategy and accords with other common views of the all-encompassing, top-down power of the Chinese Party-state. While this narrative may be useful for selling newspapers, and is rooted in the undeniable fact that China has become more powerful 
on the world stage, it fails to capture the complex behaviour and history of 'global China'. Historically, China's global presence has been a bottom-up and spontaneous affair, characterised by waves of migration sparked by economic opportunity abroad (gold mining, for example) or disturbances at home (the violence of the nineteenth-century Taiping Rebellion for instance), and facilitated by networks at the village or town level. This has resulted in Chinese communities worldwide that have tended to pursue their own interests, rather than those of 'China' writ large.

Even where Chinese people and industries have moved into Africa today in conjunction with the goals of the Chinese state, they generally fit this mould rather than one of a coherent and centrally directed engagement. Studies on Chinese communities in Africa have often found that 'the Chinese in Africa' are far from a united group that takes direct orders from their government. Instead, most of China's involvement with African economies and peoples is shaped by fragmented and divergent groups of Chinese people, many being small-scale entrepreneurs, who have little communication with each other, and even less with representatives of the Chinese government. They are also operating in a vast and highly diverse continent, making it virtually impossible to generalise about their experiences or the outcomes of their activities. ${ }^{5}$

An illustrative example of the diversified, spontaneous, and uncoordinated Chinese involvement in Africa is the ongoing gold rush in Ghana. Starting from around 2006, between 50,000 and 70,000 residents of a single, officially designated 'poverty-stricken county' 贫困县 in the Guangxi Zhuang Autonomous Region began migrating to rural Ghana to engage in alluvial gold mining. ${ }^{6}$ These fortune seekers have no connection to, or sanction from, the Chinese government, even at the local level. Rather, this mass migration is an outgrowth of the primary local vocation - the unceasing search for alluvial gold mining opportunities locally in Guangxi, elsewhere in China, and, when there is no gold to be had closer to home, globally. While many of the migrants are poor, they pool resources and borrow capital - from both formal and informal sources to buy airfares and finance the other expenses related to their quests for gold. The county's history of engaging in alluvial gold mining is long enough 


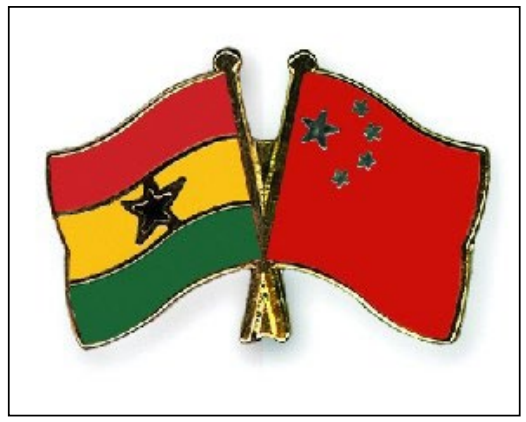

China's official strategy in Ghana is being undermined by the gold rush

Source: spy ghana, Flickr

that it has now become both part of the local identity, and an important aspect of the local economy. There are two factories producing technologically advanced dredging equipment in the county. These machines are purchased by local miners and shipped to Ghana and elsewhere in the world. ${ }^{7}$

The arrival of tens of thousands of Chinese nationals on tourist visas mining for gold - despite laws passed in 2006 specifying that only Ghanaians are permitted to engage in this activity - has fundamentally transformed local economic and political conditions in some parts of Ghana, and back in China as well. Like gold rushes throughout history, this event has produced boomtowns with new markets, and shifted local constellations of power. Some of the Chinese miners have become extremely rich. They employ both Chinese and Ghanaian workers, and sell gold to local middlemen who transfer funds directly to accounts back in China. Successful miners generally form partnerships with local entrepreneurs, tribal leaders, and government officials once they arrive in Ghana and identify a potentially lucrative mining location. They have then funnelled money (often corruptly) into local pockets, both reinforcing existing power structures, and shifting power and influence to people who previously had none. ${ }^{8}$ Successful miners and their families have been able to invest in businesses and real estate in first-tier cities and become part of the emerging cohort of wealthy Chinese urbanites.

The gold rush has also caused new fractures and fissures within Ghana's society and high politics. Tensions have arisen between individual Ghanaian and Chinese people, as well as between Accra, the Ghanaian capital, and Beijing. The introduction of new technology to scale up the extraction of gold has resulted in a host of deleterious environmental impacts - rendering fields barren, contaminating drinking water, and ultimately destroying the livelihoods of many poor and margin- 


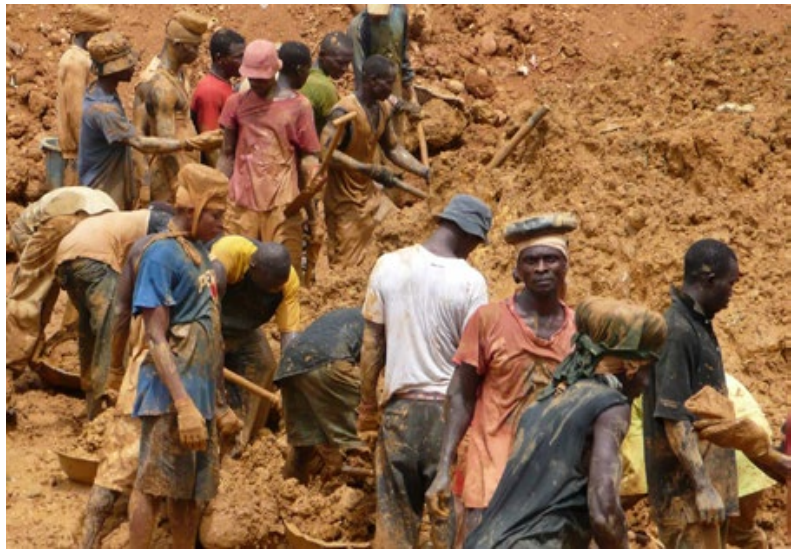

al Ghanaians. This has resulted in significant backlash against the miners, including armed conflict leading to injuries and even death. ${ }^{9}$ It has also elicited a formal government response, with former president Mahama forming a taskforce of military and police officers to raid mining camps and deport illegal miners in 2013. Since then, there has been a series of attempts to push the Chinese miners out of the country through arrests, deportations, and the destruction of equipment. In early 2017, the Ghanaian government imposed a full moratorium on alluvial mining for both foreigners and locals; this was still in place in $2018 .^{10}$

The gold rush has undermined China's official strategy in Ghana, which centres around large investments in formally approved projects.
Meanwhile, the Chinese miners demand official assistance whenever there is a crackdown, forcing Chinese officials to walk a tightrope: assisting their citizens while urging them to stop engaging in illegal behaviour that damages the image of China in Africa. ${ }^{11}$

Ultimately, the Chinese gold rush in Ghana, like so many stories of China in Africa, does not fit the narrative of a powerful monolithic Chinese state. It is, instead, the story of dispersed and fragmented power relations characterised by relatively marginal groups engaging with each other in spaces marked by postcolonial geographies, neoliberal globalisation, and new mobilities - all under the spectre of an increasingly global China. 
This text is taken from China Story Yearbook 2018: Power, edited by Jane Golley, Linda Jaivin, Paul J. Farrelly and Sharon Strange, published 2019 by ANU Press, The Australian National University, Canberra, Australia.

doi.org/10.22459/CSY.2019.07B 